fect a list of chemistry experiments concerning daily problems and publish them for members of this section. Motion carried. Committee-H. R. Smith, Chairman, Highland Park, Ill., A. C. Norris, Rockford, I1l.; C. M. Wirick, Crane High School, Chicago.

Adjournment.

Herbert R. SMith, Secretary pro tempore.

\title{
MINUTES OF THE EARTH SCIENCE SECTION.
}

The twelfth annual meeting of the Earth Science Section of the Central Association of Science and Mathematics Teachers was held in Room 19, University Hall, Northwestern University, Evanston, Iil.

The meeting was called to order at 2 p. m., November 29 th, by the Chairman, G. R. Mansfield, of Northwestern University.

The Chairman appointed the following committees:

Nominations-Mr. Peet, Lewis Institute, Chicago; Miss Henderson, State Normal, Whitewater, Wis.; Mr. Clem, Crane Technical High School, Chicago.

Resolutions-Mr. Miller, University High School, Chicago; Miss Smedley, Joliet High School; Miss Mannhardt, Evanston High School.

Prof. W. H. Burge, Northwestern University; then gave an illustrated lecture on "The Earth Measurer, His Life and Work." Fol. lowing is an abstract of same:

"The U. S. Coast and Geodetic Survey is engaged in making earth measurements of the highest attainable accuracy. Excluding island possessions, the United States has over 10,000 miles of shore line which must be mapped and charted and resurveyed from time to time on account of constant changes. This is done by plane table surveys and by sounding, the location of the soundings being determined by the sextant or some other instrument.

. "The plane table is also used for interior surveys, boundary surveys, etc. The method used is called triangulation. A base line is measured forward and backward by tape with an accuracy of one part in a million, so that the two results over a base one mile in length differ only by $6 / 100$ of an inch. The position of one end of the line is found by astronomical means and its true bearing is determined. A third point visible from both ends of the base is selected and the angles of the triangle thus formed are then measured by means of a theodolite placed at each angle of the triangle. By trigonometry the lengths of the other sides are determined and then the latitude and longitude of each corner is computed. The sum of the three measured values of the interior angles of a triangle seldom varies from the true value by more than three seconds of angle and in more than half the cases the difference is less than one second of angle. Lines from the eye to the edges of a foot board forty miles away make an angle of one second. The sides of the first triangle may be used as bases for other triangles and so the survey is expanded in the desired direction, a circuit being planned so as to close on the starting point or on some point, the position of which has been previously determined.

"Obstacles in the line of sight are surmounted by various devices, notably by the construction of rigid observation towers, frequently ninety feet or higher and so constructed as to form really two towers', one within the other. The instrument is placed on the inner tower, while the observer stands on the outer one within the instru- 
ment shelter. The course of the proposed survey is traversed in advance by a reconnaissance man or party that selects the points of observation and erects towers. No place is too difficult to penetrate or climb and a high degree of courage and shrewd judgment are required of all men engaged in the work, but, particularly of the reconnaissance man.

"For the longer sights an instrument, the heliotrope, consisting of mirrors directed by sights, as in a riffe, is used in connection with powerful bicycle or automobile acetylene lights in night observations. The longest sight ever taken by this method was from Mt. Uncompagre in Colorado to Mt. Ellen in Utah, a distance of 192 miles. The heliotropes and lights are in charge of light keepers, whose movements are directed by flashes in accordance with the telegraphic code.

"The life of the earth measurer, though full of hardship, has many fascinations."

The Committee on Methods of Testing Results of Teaching Physiography gave their final report. Mr. James H. Smith, Austin, I1l., read the results of three tests that had been sent to teachers and given to pupils in twelve schools. This report has already been published in full in School Science and Mathematics, Vol, XII, No. 7, October, 1912, pp. 616-626. The report of the committee was accepted and the committee discharged.

Motion carried that since no formal report could be given by the Committee on Coördination of Science Teaching in High Schools until similar committees had been appointed by the other sections of the Association, the Committee on Coördination of Science Teaching in the High Schools be discharged.

The second session was called to order at 10:30, November 30th.

Dr. J. Paul Goode gave the following lecture: "The Philippines: The Land and the People." (Illustrated.)

The paper was an intensely interesting summary of the geography of the islands, including position; extent, climatic features, vegetation, peoples, pursuits, and economic possibilities. Some of the problems to be faced by the United States government in the development of the islands were indicated. The remarkable progress made by the United States in the Philippines during the past fourteen years was outlined, a record far surpassing that of any other nation that has made any attempt to colonize the tropics. In the opinion of the speaker the islands may not be abandoned by the United States government without a lapse into chaotic conditions and probable annexation by some other power-Germany or Japan.

The Committee on Nominations reported its recommendations: Miss Zonia Baber, University of Chicago, Chairman; Prof. U. S. Grant, Northwestern University, Vice-Chairman; Miss Annie Weller, Charleston, Ill., Secretary. These persons were elected.

The Committee on Fundamentals, W. E. Durstine, Chairman, reported. In the absence of the chairman, the report, an outline for two years' work in the high school, was read by Miss Henderson. The report was accepted and the committee discharged.

The Committee on Resolutions, George J. Miller, Chairman, reported as follows:

$\mathrm{Be}$ it

Resolved, That in accordance with the report of the Committee on Methods of Testing Results of Teaching Physiography, that similar tests be given to show the ability of the pupils to apply principles of physiography; and, be it 
Resolved, That a committee be appointed to report on a suitable collection of pictures and other illustrative material which will give a pupil more practice in interpreting geographic principles; and, be it

Resolved, That a committee be appointed to submit plans for a four years' course in geography which shall include suitable subject matter in sequence; and, be it

Resolved, That the Earth Science Section use its influence to bring about the conservation of natural areas essential in the teaching of geography and allied sciences; and, be it

Resolved, That the Earth Science Section tender a vote of thanks to Northwestern University for hospitality extended to the association.

George J. Miller, Lydia M. Smedley, Mita Mannhardt, Committee. Bertha Henderson, Secretary.

\section{MINUTES OF THE MATHEMATICS SECTION.}

The Mathematics Section of C. A. S. and M. T. held two meetings at Northwestern University, Evanston, Ill., Friday and Saturday, November 29 and $30 ; 1912$.

\section{Friday Afternoon Session.}

Since the chairman, Mr. Ira S. Condet, was unable to be present, Mr. Charles W. Newhall, the vice-chairman, presided.

The following nominating committee was appointed: $\mathrm{Mr}$. C. E. Comstock, of Peoria, Ill., Chairman; Miss Jane Pollock, Kenilworth, I1l; Mr. R. L. Short, Cleveland, Ohio.

$\mathrm{Mr}$. C. E. Comstock gave the report of the Committee on Results, which was continued from 1911. He said that the committee were not sufficiently agreed to make a printed report at this time; but mentioned the following, on which they were agreed:

1. That tests should be made on the amount of algebra which a pupil should be expected to retain at the end of the first year; of geometry at the end of second year; and of algebra at the end of the last year.

2. That the time element is important in mathematical ability.

3. In reading and spelling, powers are always retained; but how much knowledge of algebra does the pupil retain? The committee wants to establish a scale by which one can measure one's own school, a test in algebra, similar to those already made for handwriting and arithmetic.

For special problems, these tests were suggested:

1. Simple expansions.

2. Tests of exponents.

3. Factoring.

4. Simple equations.

5. Addition of fractions.

6. Radicals.

7. Translation.

In the informal discussion which followed, it was suggested by Mr: Hart, of Wisconsin, that these questions be investigated:

1. Can a pupil get something from the book?

2. Can he get something from the class?

3. Can he prove an original?

It was moved by Mr. Collins, seconded by. Mr. Jocelyn, and carried, that the report be accepted and the committee continued; 